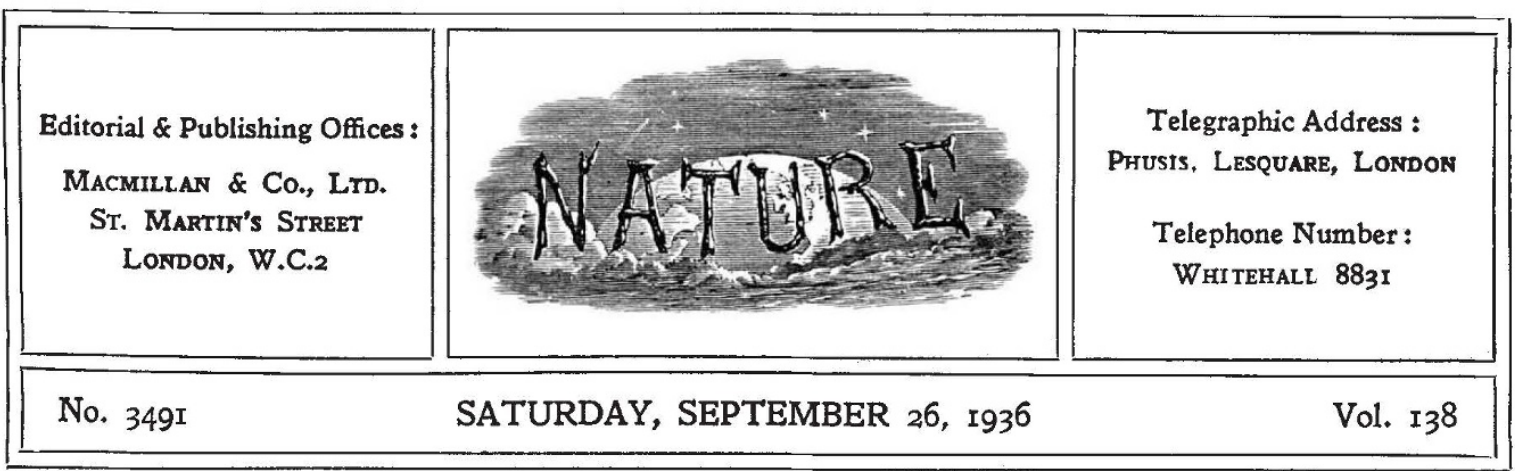

\title{
Human Tendencies
}

$\mathrm{I}^{\mathrm{N}}$ the annals of the British Association there will be found not one but many landmarks in the history of science. The Blackpool meeting of 1936 , it is probable, will stand out as a whole, certainly in popular memory, as the one meeting above all others which from the inception of the Association up to that date has endeavoured to address itself on a united front to a diagnosis of the current ills of human society. The presidential address, no less remarkable for its controlled imagination than for its keen insight into and power of analysis of complex social phenomena, set the keynote of the meeting; and it was a striking testimony to the sense of responsibility to the community which is felt by the men of science of to-day that the lead given by the president of the Association was followed not alone by the sections dealing with the biological and humanistic sciences. Even a branch of study so academic so apparently remote from the stress of current social problems as palæontology, afforded Prof. H. L. Hawkins in the presidential address to Section C (Geology), part of which appears in this issue of NATURE (p. 534), the material for pungent comment on current tendencies in human development.

It is possible, however, that on reflection there may appear no paradox in the fact that a science such as palæontology, of which the data are far removed from current events, should nevertheless provide a canon of criticism for tendencies of to-day. Although we may feel inclined to qualify Prof. Hawkins's dictum that our knowledge of the ancient Romans is at best equal to our knowledge of the trilobites, yet we may agree that as we can here view the beginnings, the prime, and the decay of long extinct species more clearly and more objectively than we can observe the rise and decline of the powers and empires of the past, so we may perhaps deduce from them more certainly the operation of biologieal laws which affect the evolutionary process in human affairs, no less than those which govern that process in the development of man himself.

Prof. Hawkins led his audience from stage to stage of evolution in organisms of the past to the emergence of man himself. It might seem a sorry commentary on his text for those who believe in the evolutionary process as a progression in perfectability to turn to the discussions and addresses in other sections, and to see what man has made of himself in the vast interval of time which has elapsed since that first emergence. There they would have found that man of to-day was being brought to the bar of judgment for handling the dangerous instruments of which scientific development has given him control with the mentality of a schoolboy, and as Lord Horder pointed out in the discussion on "The Strain of Modern Civilization", indicted as the subject of neuroses and auto-infection, because he has allowed himself to fall a vietim to the organization which he himself has built up (see p. 529).

It is unfortunate that on the anthropocentric view imposed upon us by the condition of our being, the evidence of palæontology as an objective standard of progress should cease to be operative with the coming of man. When once man as such has evolved, palæontology can tell us little further of really fundamental and significant organic change. Unless mere size of brain be the criterion -in which event man may have surmounted the peak of his development with the passing of Neanderthal man, and modern man actually represent the entry on a phase of decline-on the coming of the modern man with his more highly 
convoluted brain, that page of evolution is closed, in any event for the present, whatever the future may hold. From that point onward, throughout man's strenuous struggle to build up civilization, the evidence of change in man is indireet-and neither palæontology, archæology nor, except to a limited degree, history tells us what functional change may have accompanied his further development. Man as we see ex post facto, at the time of his emergence, is differentiated from his contemporaries of the animal world by the spirit, and by its achievement he should be judged. Less well equipped than any other animal approaching him in size with either protective covering or strength of tooth and claw, yet he is less at the mercy of his environment. Armed with the most powerful weapon of defence and destruction that Nature has forged, the human brain, he has conquered his environment so that not only has this otherwise defenceless creature made himself master of every quarter of the globe, irrespective of climatic and other environmental conditions, but also he is exterminating or subjugating all animal life, while exploiting all natural resources as well as conquering the air and drawing treasure from the depths of the sea. Hence man's progress in fact is commonly measured by his control of the material resources of the world.

It is scarcely necessary to stress the point to which this assessment of human progress in materialistic terms has brought us. A century of expansion and, on the whole, uninterrupted advance in every department of civilized life has now received a check. A prolonged period of economic depression and disturbed political conditions, international as well as in some instances internal, has dislocated what had come to be regarded as the normal flow of life, and has induced a wave of pessimism, which questions the values of what has hitherto been regarded as progress. Even the very fact whether man has progressed at all, at least since the early days of his emergence from barbarism, is brought into dispute. More grave, because more fundamental, is the judgment implied in the suggestion that 'progress', like Frankenstein's monster, has outrun the power of man to control it, and that therefore scientific investigation, which by its effect on production and therefore on labour is regarded as chiefly responsible, should be slowed down to enable consumption and employment to make good the lag rapidly forming a vicious circle from which extrication will be difficult or impossible. Although the British Association neither generally nor specifically in the meeting at Blackpool is legitimately to be regarded as the foster parent of pessimism, nor would be prepared to admit the ultimate sanity of any suggested check on scientific research or its application to practical affairs, yet the unanimity shown by the sciences in the recent debates in diagnosing the underlying causes of the present situation as in some way or other involved in a lack of conscious direction, marks recognition of the gravity of the evil at the same time as it seems to point a way out.

The complaint that the strain of contemporary life is too great for human endurance is probably as old as the association of human beings in anything larger than a family group. Nor is it always the part of the laudator temporis acti. It certainly goes back so far as Horace when he longed for the quiet of his Sabine farm; it is familiar in the eighteenth century, as for example in the works of Smollett, and Sir Josiah Stamp quoted an apt example from the "Creevey Papers" in the reference to the "frightful" experience of travelling by rail at the rate of twenty-three miles an hour. These plaints, however, date from before the days of the machine, when individuality still had room for play. The more strenuous nineteenth century, with its doctrine of laisser-faire, encouraged the struggle of the individual, while imposing conditions upon labour and production against which it was the sense of the community that the worker should be protected. It is unnecessary to recapitulate the familiar story of the social and industrial development of the nineteenth and early twentieth century; but the principal trends which are germane to the present purpose are the growth of associations of both labour and employers, the application of scientific methods and results to all departments of production, as well as to the wellbeing of the worker, and the recognition by the community of its responsibility to see fair play as between employer and employed and the consumer and the producer, as well as generally to preserve so far as possible some balance between the rights of the individual and the claims of the group, whether trade organization or public authority.

The application of these principles to a large extent was opportunist, and so far as concerns the application of scientific methods and results to the problems of society and industry, was often more or less a consequence of pressure, frequently considerable, brought to bear on authority from 
outside. Much has happened since then; and of all the lessons of the Great War, the most enduring and the most far-reaching have been the value of scientific research when applied to the problems and needs of practical life, and the impetus which can be imparted to concerted group effort under direction.

Of these two lessons the latter was already in principle familiar to the anthropologist. It is a form of the struggle for existence whereby man seeks to secure survival through combination in groups which ever increase in size and complexity. As a result of experience in the War, this principle has been transformed into a political dogma. It has produced on pseudo-scientific argument the totalitarian State, whether communist, fascist or quasi-constitutional under a virtual dictator.

The weakness of the totalitarian State is as obvious as its strength. It exalts the whole at the price of individuality, and in so far as it must in self-protection stamp the individuality of the many with the brand of the few, however wise and provident they may be, it will in the long run weaken the whole. For the group to survive must survive through the quality of its individual components. The problem of future research in the biological and humanistic sciences is to solve the equation of group interest and individual wellbeing. As Sir Josiah Stamp indicated in his presidential address to the British Association, the crisis in world economics and politics has forced it on our attention that there is a vast field in the constitution and character of man, his heredity, his training, his social and economic relations, more especially in relation to changing conditions, which await investigation. However intense and far-reaching may be the efforts of research directed to the improvement of material conditions, the result may be, who can say, perhaps more harm than good unless we understand more elearly than we do at present the whole nature of man and his reactions both as a unit and in the group. In the long run, the race will be to those who solve this problem.

\section{A Text-Book of Unapplied Biology}

Why Keep Them Alive?

By Paul de Kruif, in collaboration with Rhea de Kruif. Pp. vii +293 . (London: Jonathan Cape, Ltd., 1936.) 10s. $6 d$. net.

$\mathrm{D}^{\mathrm{R}}$ R. PAUL DE KRUIF is a writer better known, unfortunately, in his own country than in England. Beginning life as a bacteriologist, he soon abandoned academic science and research, and devoted his talents to the vulgarization (in the French sense) of scientific and medical discoveries--becoming, in his own words, "a sort of human loud-speaker, a barker", telling the world at large about some of the wonders of biology. In "Microbe Hunters" (1926), "Hunger Fighters" (1928), "Men against Death" (1932), he has already related, in colloquial American language, various outstanding 'triumphs' of bacteriology, nutritional physiology, and medicine. All these books are distinguished by the accuracy of their scientific and bistorical data, though these are often presented in a picturesquely overdrawn manner and from a national point of view not always appealing to a more stolid English audience.

As our author has already employed his scientific knowledge and literary gifts to good purpose, we turn to his latest work in confident expectation that he has again some arresting news to announce.
And he has. He has discovered that the scientific and medical marvels which he formerly chronicled so dramatically and so hopefully are not being properly used for the benefit of humanity. Despite all our new knowledge--which he has already been at such pains to broadcast-about microbes, vitamins, and hormones, he finds that American citizens are still dying off like flies from starvation and avoidable afflictions. So he asks with righteous indignation why this is so. If we have not the sense to keep even our innocent little children alive and well in a world of knowledge and plenty-to stop them dying from starvation, and from preventable and curable diseases-why in Heaven's name do we let them live at all ?

Both the contents and the temper of this disturbing book can be briefly indicated by the titles of its chapters (I almost said "the texts of its sermons"). (1) Why should they die? (2) Discovery that children are forgotten. (3) Discovery that it's dollars or children. (4) The power of science without money. (5) The people's deathfight. (6) Drouth is a blessing. (7) Who owns our science? (8) Observation of children of the shadows. (9) Should children eat? (10) Children can live! These headings give but a faint idea of the variegated and confusing pattern of the whole : yet the reader who conscientiously follows 